\section{AZOK A MAI FIATALOK - GENERÁCIÓS KÜLÖNBSÉGEK A BIZTOSÍTÁSI SZOKÁSOKBAN}

Szöke Péter *

Kulcsszavak: X és Y generáció, kérdőíves felmérés, biztosítási szokások, személyi pénzügyek

JEL: J100, C83, D14

DOI: $10.18530 /$ BK.2015.3.30

http://dx.doi.org/1018530/BK.2015.3.30

\section{öSSZEFOGLALó}

Nagyon sokszor tapasztaljuk, hogy a fiatalabb generációk sok mindenben másként gondolkodnak, sok mindent másként csinálnak, mint az idősebbek. A KPMG egy 2015 májusában végzett belső munkatársi kutatáson keresztül azt vizsgálta, hogy az X (az 1965 és 1979 között születettek) és Y generáció (az 1980 és 1995 között születettek) közötti általános különbségek mennyire érvényesülnek a biztosítási szokásokat illetően. Mennyire és mennyiben kell a biztosítóknak alkalmazkodniuk a fiatalabb generációk elvárásaihoz, szokásaihoz, illetve milyen eszközökkel tudnak a lehető legjobban megfelelni a legjobban fizető X, valamint a felnövő Y generáció igényeinek.

Tíz kérdéskörben vizsgáltuk a generációs jellemzőket és eltéréseket: megtakarítási szokások, félelmek és biztosítottság, biztosítás kötésére motiváló tényezők, informálódási szokások, értékesítési csatornák igénybevétele, legfontosabb tényezők a biztosításkötésnél, biztosítókkal való elégedettség, biztositóválasztási tényezők, elégedettség a biztosítási termékekkel, valamint az innovációk iránti nyitottság.

\section{Bevezetés}

Nagyon sok témában tapasztaljuk, hogy a fiatalabb generációk sok mindenben másként gondolkodnak, sok mindent másként csinálnak, mint az idősebbek. Mielőtt megnéznénk ezeket a különbségeket, lássuk pontosan, milyen generációkról beszélünk.

\subsection{Generációk / Definíciók, jellemzők}

A Baby boom generáció egy része alapvetően értetlenséggel figyeli a viselkedési minták technológiai fejlődés/változás okozta átalakulását. Ők pontosan érnek oda a megbeszélésekre, rosszul viselik, ha valaki fél órával korábban mondja le részvételét, vagy kezdeményezi a program átalakítását. A net alapfunkcióit kedvelik, e-maileznek, facebookoznak, de az újabb és újabb lehetőségeket nem ragadják meg, nem szerkesztgetnek fényképeket, nem töltenek

\begin{tabular}{|c|c|c|c|}
\hline & Születési év & Munka & $\begin{array}{c}\text { Technológiai } \\
\text { változással való } \\
\text { szembesülés időszaka }\end{array}$ \\
\hline Veteránok & $1925-45$ & $\begin{array}{c}\text { Nyugdijasok, de } \\
\text { a legfiatalabbak is } \\
\text { maximum } 10 \text { éven } \\
\text { belül visszavonulnak. }\end{array}$ & $\begin{array}{l}\text { Életük második } \\
\text { felében találkoztak az } \\
\text { internettel. }\end{array}$ \\
\hline Babyboom & $1946-64$ & $\begin{array}{c}\text { Jelentős hányadát } \\
\text { teszik ki a } \\
\text { munkaeröpiacnak. }\end{array}$ & 30-40 életév között. \\
\hline $\mathrm{X}$ generáció & $1965-79$ & $\begin{array}{l}\text { A munkaeröpiac } \\
\text { gerince. }\end{array}$ & $\begin{array}{l}\text { Kamaszként / } \\
\text { tinédzserként. }\end{array}$ \\
\hline Y generáció & $1980-95$ & $\begin{array}{l}\text { Heterogén csoport } \\
\text { (Tanulók, kezdő } \\
\text { munkaerö, és } \\
\text { már akár 10-15 év } \\
\text { munkatapaszatalattal } \\
\text { rendelkezők). }\end{array}$ & Gyermekkorban. \\
\hline Z generáció & $1996-$ & $\begin{array}{c}\text { Tanulók, néhány } \\
\text { év múlva kezdenek } \\
\text { megjelenni a } \\
\text { munkaerópiacon. }\end{array}$ & $\begin{array}{l}\text { Nem éltek internet } \\
\text { nélküli világban. }\end{array}$ \\
\hline
\end{tabular}

1. táblázat - Generációk általános bemutatás

Forrás: Kulcsár Zsolt: Az integratív e-learning fele

le appokat, és sokkal jobban kötődnek az időben korlátozottan elérhető tartalmakhoz (tv, rádió), valamint a nyomtatott olvasnivalókhoz.

Alapélményük az internet előtti világ, összejárnak, átmennek egymáshoz, és ma is többet adnak ezekre a kapcsolatokra, mint a fiatalabb generációk, bár egyre kevésbé engedhetik meg maguknak az utazást vagy az azzal járó költést. Vásárlási szokásaikban a régi, megbízható dolgokat részesítik előnyben, az újak szerintük hamar tönkremennek. Beszerzéseik során szeretik megvizsgálni, kézzel fogni, érinteni a beszerzés tárgyát, de kitűnő lehetőséget látnak a használt cikkeket kínáló weboldalakban, hogy régi vágyaikat kielégítsék.

$\mathrm{Az} \mathrm{X}$ generáció tagjai kamaszként találkoztak életükben először az internet nyújtotta lehetőségekkel, és azt alapvetően felszabadulásként élik meg. A kitágult világot, az információ szabad áramlását, az internet nyúitotta kényelmi lehetőségeket hajlamosak kegynek tekinteni, egészen addig, amíg nem szembesülnek a Z generáció, azaz saját gyerekeik életvitelében betöltött szerepével. Ilyenkor előtör belőlük a „bezzeg, amikor mi voltunk gyerekek, voltak igazi élő barátaink" életérzés. Ugyanez a kettősség figyelhető meg náluk az internet használatát illetően is. Miközben úttörő szerepet játszottak a zeneipar átalakulásában és általában a push típusú tartalom előállítással szemben a pull típusú tartalomszolgáltatás sikerre vitelében (ők voltak az első tényleges előfizetői az ilyen csatornáknak), ma már idegenkedve szemlélnek több újdonságot is a weben. 
Egyre nehezebben alkalmazkodnak az új kezelö felületekhez, ritkábban tanulnak meg valami újat, mint az Y generáció tagjai, így lassan kiöregszenek a változásból, nem ritkán szószólóivá is válnak a netet korlátozni óhajtóknak, vagy előszeretettel alkalmaznak olyan korlátozó eszközöket, amelyekkel a szülők megakadályozhatják gyermekük internetes „ámokfutásait" vagy a szabadosnak ítélt tartalmak elérését. Fogyasztási szokásaikban mindez a személyes adataik nagyobb mértékủ féltésében érhetö tetten a leginkább. Míg az Y és a Z generációk tagjai gond nélkül adják ki személyi adataikat vélt vagy valós kényelmi szolgáltatásokért, alacsonyabb árakért cserébe, addig az X generációból sokan féltik a privát szférájuk biztonságát, és próbálnak ellenállni annak, hogy érdeklődési körüket vagy fogyasztási szokásaikat könnyedén feltérképezzék.

Az Y generáció tagjai a mai huszonévesek és fiatal harmincasok, az információs kor gyermekei. Világukban mélyen megváltoztak az érintkezési szokások, és átalakultak olyan hagyományos fogalmak, mintértékrend, tudás és tekintély. A személyes kapcsolatok háttérbe szorulnak, a törzsi hovatartozás élményét nem az osztályukból, a szomszédságból vagy a sportból nyerik, hanem az internetről, nem ritkán olyan emberektől, akiket élőben még sosem láttak, vagy akinek a konkrét életkorát sem ismerik. Ebben a közegben felértékelődik a vizuális képzelőerő, a nyelvi készségek, az íráskészség, ugyanakkor a személyes kapcsolatok hiányában kevésbé fontossá válik az emóció, az érzelmek közös feldolgozása.

De nemcsak a közösségi élmény alakul át, hanem a vásárlási szokások is. A választásokban felértékelödik olyan távoli személyek vagy profi csapatok (tesztoldalak) véleménye, amelyek megbízhatóságáról kizárólag a közösségi oldalakon, blogokon tud véleményt alkotni a felhasználó. Maga a vásárlás is átterelődik az internetre, így a közvetlen tapasztalás, a válogatás és a tapintás élménye háttérbe szorul mások véleményéhez és a külcsínhez képest. Ez a folyamat olyan homogenizált termékekkel kezdődött, mint a könyv (lásd: Amazon felfutása), de mára olyan bevásárlási célpontokra is kiterjedt, amelyeknél korábban sosem bíztuk volna magunkat másra (például: élelmiszerek).

A Z generáció az Y-hoz hasonló tulajdonságokat mutat, de mindaz, amit ott leírtunk, fokozottan érvényes rájuk. Az Y generációhoz képest nagy változás, hogy sokkal kevesebbet mond nekik az előre összeállított tartalom (tv, rádió), mint az Y generációnak, ugyanis már gyerekkorban hozzászoktak ahhoz, hogy az őket érdeklő tartalmakat, legyen az film, könyv, zene, játék vagy bármilyen videó, választják és lehívják. Ennélfogva megváltozik az időérzékelésük, nem kötődnek konkrét időpontokhoz, mindent akkor és ott fogyasztanak, amikor éppen akarnak. Ez ugyanúgy kihat a vásárlási és ügyintézési szokásaikra, ahogy az Y generációra hatott a személyes kapcsolatok háttérbe szorulása.

\subsection{A kutatás}

A kutatás során azt vizsgáltuk, hogy a fentebb bemutatott általános generációs különbségek mennyire érvényesülnek a biztosítási szokásokat illetően. Mennyire és mennyiben kell a biztosítóknak alkalmazkodniuk a fiatalabb generációk elvárásaihoz, szokásaihoz, illetve hogyan milyen eszközökkel tudnak a lehető legegyszerübben megfelelni a legjobban fizető X, valamint a felnövő, a szektorban ma még nem számottevő költőnek tekinthető Y generáció igényeinek.

\section{A minta demográfiai és társadalmi sajátosságai}

A kutatás a KPMG munkavállalói között zajlott. Ez a csoport zömében X és Y generációhoz tartozó munkavállalókat jelent. Valamennyien jó életpálya-kilátások elé néznek, nyelveket beszélnek, az átlagnál erősebb számítógépes ismeretekkel és magasabb jövedelemmel rendelkeznek, ennélfogva fogyasztói tudatosságuk is erősebb, értékválasztásaik világosak, nehezen megingathatók. Fontos szempont volt a minta értékelésekor, hogy a felelős munkakör és a belső légkör miatt a cég alkalmazottai jól és bátran artikulálják a véleményüket, így a szerezhető adatok feltehetőleg sokkal precízebbek, mint más, nagyobb és reprezentatív minták vizsgálatakor.

A kiadott 750 kérdőívből végül 200 darab érkezett vissza maradéktalanul kitöltve, és ezen válaszok alapján készültek el a későbbiekben bemutatásra kerülő elemzések. A válaszadók demográfiai mutatói elég jól leképezték a megkérdezettek körét. A válaszadók 96 százaléka az X és az Y generációba tartozik. A többség (75\%) az Y generációba sorolható.

A mintában szereplők 60 százaléka többszemélyes háztartásban él, de 75 százalékuknál még nincs gyerek. Meghatározó tehát a DINKY (Double Income, No Kids Yet) jelenség, ezért a családi és az egy före jutó jövedelem is messze az átlag fölötti tartományba sorolható. Az egy háztartásra jutó jövedelem a legfelső jövedelmi decilisbe emeli a mintát, ami természetesen azt is jelenti, hogy az eredmények értékelésénél és esetleges felhasználásánál ezt kiemelten figyelembe kell venni.

A hosszú távú pénzügyi döntéseket a megkérdezett $X$ generáció 9 százaléka, az $\mathrm{Y}$ esetén 11 százaléka egyedül hozza meg, a többi esetben a pároknak is van ebben szerepük. Meglepő módon az életkor előrehaladtával csökken a párok összhangra törekvése, feltehető, hogy a régebbi háztartásokban az egyik fél nem is akar ezekkel a kérdésekkel foglalkozni. Míg az Y generáció esetén 61 százalékban teljesen egyforma súllyal vesznek részt a döntésben a felek, addig az X-nél csak 48 százalékban, a többi esetben az egyik fél nagyobb súllyal vesz részt a döntésekben, mint a másik.

\section{A kutatás eredményei}

\subsection{Megtakarítási szokások}

A munkahely és a magas jövedelmi pozíció a kitöltők 96 százalékát arra predesztinálja, hogy érdemben foglalkozzon a megtakarításaival. Ez 6 százalékuknál elméletben zajlik, mivel nincs tényleges megtakarítása, 90 százalékuknak azonban van min gondolkodni. Az Y generáció megtakarításai értelemszerüen alacsonyabbak, ők jellemzően 25 és 50 ezer forint közötti megtakarítással rendelkeznek havonta ( 28 százalékuk), az X generációban azonban a havi 100-250 ezer forint megtakarítás a leggyakoribb, de 20 százalékuk ennél is többet tud félretenni. Azt összességében elmondhatjuk, hogy mindkét generáció döntő többsége ebben a jövedelmi szegmensben legalább 25 ezer forintot rendszeresen megtakarít. 
A megtakarítási formákat illetően az X generáció tagjai láthatóan tudatosabbak, de az egész mintáról elmondható, hogy mindkét generáció általában a kockázatkerülő megtakarítási formákat részesíti előnyben. A kockázatkerülésről vagy talán inkább a pénzügyekre való oda nem figyelésről sokat elárul, hogy a mintában szereplök nagy aránya tart megtakarítást a folyószámláján, ahol gyakorlatilag nulla hozamot lehet elérni. Érdekes lehet ennek az időbeni változását figyelemmel kísérni, mert ez a magatartás még betudható a nem is olyan régi magas kamatkörnyezetnek vagy az alternatív befektetésekkel kapcsolatos botrányoknak. Az Y generáció 54 százaléka tart megtakarítást folyószámlán, míg az X generációnál ez az arány már csak 37. Ezzel szemben magas a lekötött betét, a megtakarítási számlák és befektetési alapok aránya, valamint az államilag támogatott megtakarítási lehetőségek kihasználása. Ez utóbbiból az X és az Y generáció érdekes módon egyaránt hasonló arányban veszi ki a részét. (1. ábra)

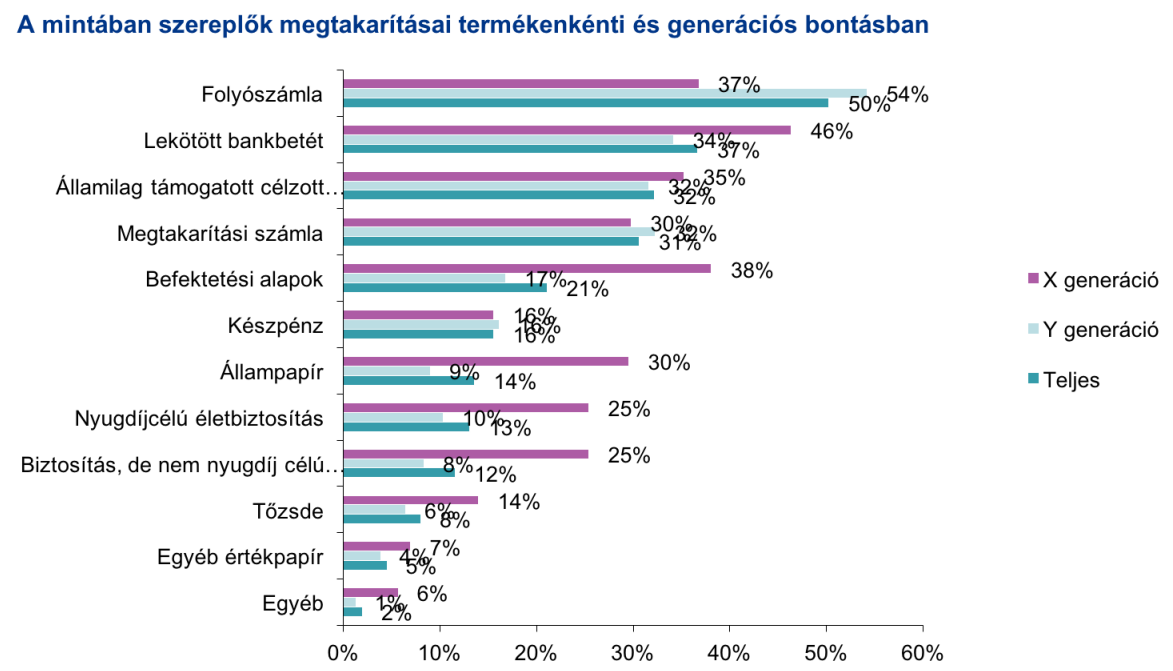

1. ábra - A mintában szereplök megtakaritásai (Forrás: KPMG belső kutatás 2015)

A biztosításalapú megtakarítások esetében óriási, majdnem háromszoros az eltérés a két generáció között, természetesen az X javára. Ezen generáció 25 százaléka tart nyugdíjcélú életbiztosítást, szemben az Y generáció 8 százalékával, ami logikus, hiszen ebben az életkorban a nyugdíj még távoli, míg például az autó- vagy lakásvásárlási igény nagyon is közeli probléma. Nem nyugdíjcélú életbiztosítást már a fiatalok közül is többen kötnek, 10 százalékuk mondhat ilyet magáénak, míg az X generáció tagjai közül 25 százaléknak van nem nyugdíjcélú életbiztosítása.

Tőzsdei és értékpapír-alapú megtakarítások esetében is többszörös az eltérés az X generáció javára.

\section{Tanulságok a biztosítók számára}

Azt láthatjuk, hogy az adott jövedelmi szegmensben nemcsak a megtakarítási hajlandóság nagyon nagy, de az effektív megtakarított összeg is számottevő már az Y generáció esetében is. Ennek ellenére még ebben a szegmensben is meglehetősen konzervatív, rövid távú és/vagy nem túl tudatos megtakarítási stratégiákat látunk, föleg az Y generációnál. A pénzügyi oktatás, a bonyolultabb megtakarítási termékek hatékonyabb ismertetése mindenképpen hasznos lenne, persze ez nem feltétlenül csak a biztosítók feladata.

Másrészt látszódik az Y és X generáció között az a szakadék, hogy a biztositásalapú megtakarítások esetében háromszoros a penetráció az X generációnál, tehát kritikus minden biztosító számára megtalálni azt az időpillanatot és azt a terméket, amellyel az Y generáció adott tagja sikeresen megcélozható. Ebben segítséget ad az adatalapú ügyfélelemzés, ami az ügyfélprofilozás, termékaffinitás és ügyféléletgörbe-elemzés segítségével sokkal hatékonyabbá teszi a kampánytevékenységet.

\section{Meglehetősen konzervatív, rövid távú és/vagy nem túl tudatos megtakarítási stratégiákat látunk.}

\subsection{Félelmek és biztosítottság}

A vizsgálatban azt is megkérdeztük, hogy milyen biztositási eseményektől tartanak a legjobban, és azok bekövetkeztét mennyiben fedezik biztositásokkal az érintettek. Meglepő módon ebben a tekintetben a válaszadók nem mutatkoztak olyan racionálisnak, mint amire társadalmi státuszuk és magas képzettségük alapján következtettünk volna. Saját félelmeihez képest mindkét generáció messze túlbiztosítja utazásait. Az X generáció lakásbiztosítási lefedettsége messze meghaladja a káresemény bekövetkeztétől való félelmeit, e tekintetben viszont a fiatalabbak sokkal racionálisabbnak mutatkoznak. Fordított előjellel ugyanez valósul meg a gépjármü-biztosításoknál is, itt a fiatalok az indokoltnál kevésbé fedezik a kockázatokat, az idősebbek viszont félelmeiknek megfelelő lefedettséggel bírnak. (2. ábra)

Mindkét generációra igaz, hogy meglevő aggodalmaiknál sokkal kisebb mértékben fedezik a nyugdíj- és az egészségügyi kockázataikat. Az általunk használt ötfokú skálán messze az X generáció nyugdígondjai kapták a legnagyobb félelemindexet (csaknem 4-esátlag), ehhez képest saját megítélésük szerint az ezzel kapcsolatos kockázatokat csak mintegy 10 százalékban fedezik létező biztosításaik. Bőven a 3-as félelemindex felett vannak ezzel a fiatalabbak is, de az ő fedezettségük még alacsonyabb, mindössze 7 százalékos. Az egészségügyi kockázatok az X generációtól ugyancsak 3 feletti félelemindexet kaptak, de a fedezettség itt már 36 százalékos. Az Y generáció ugyanilyen mértékben fedezi egészségügyi kockázatait annak ellenére, hogy ezzel kapcsolatos félelmeik még értelemszerüen alacsonyabbak.

\section{Tanulságok a biztosítók számára}

Három olyan terület látszódik, ahol a káreseménytől való félelem messze meghaladja a biztosítottsági szintet. Generációs eltérés egyetlen terméknél, a cascónál figyelhető meg. Itt az a hipotézisünk, hogy az alacsonyabb jövedelem miatt nem telik biztosításra, illetve 


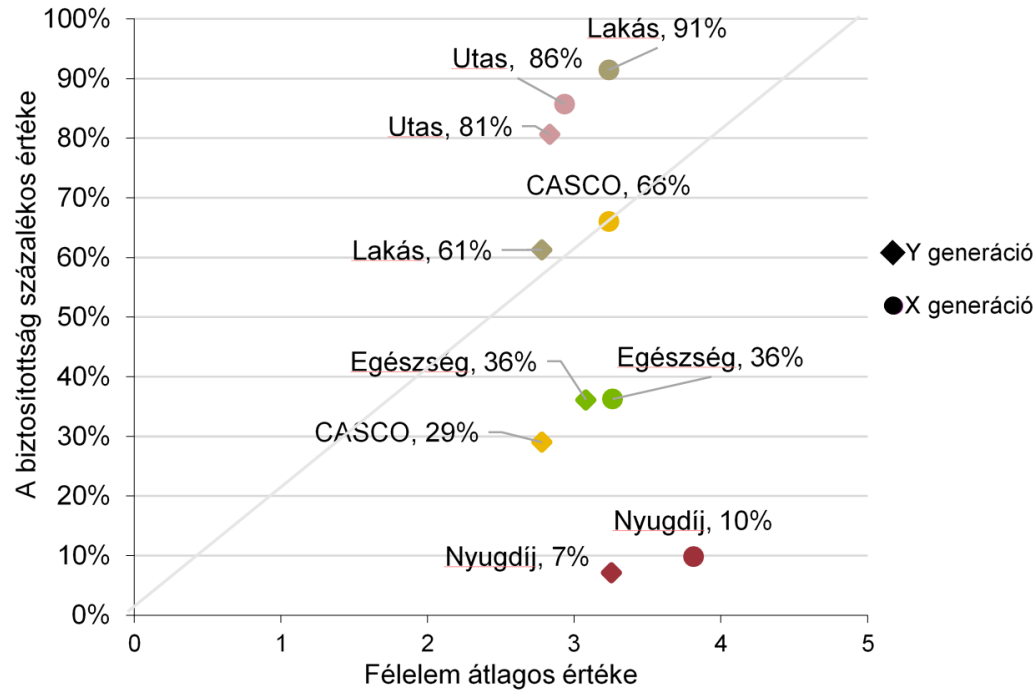

2. ábra - Fôbb különbségek a káreseménytöl való félelem és a biztositottság viszonyában (Forrás: KPMG belső kutatás 2015)

feltételezhetően a kisebb értékű, régebbi gépkocsi miatt könnyebben átsiklanak ezen a félelmen a fiatalok, vagy nem casco-képes járművel rendelkeznek nagyobb arányban. Itt a biztositók olyan új termékekkel, megoldásokkal érhetnek el sikert, ahol csökkentett díjjal lehet biztositást kötni a megfelelö kockázati kategóriába tartozó ügyfeleknek. Erre a használatalapú (pay as you go), illetve a vezetési stílustól, használati módtól függő árazású, például telemetriát használó megoldások lehetnek alkalmasak. Az első kezdeményezések már elindultak a hazai piacon is, érdemes szemmel tartani az eredményeket.

A nyugdij- és egészségbiztosítási penetráció növelése jóval keményebb feladatnak tűnik, mert még az idősebb korosztály sem tủnik hajlandóbbnak ezen termékek megvásárlására. Itt is az oktatás, a hosszabb távra tervezés szükségességének elfogadtatása lehet a megoldás, de ettől természetesen inkább csak hosszabb távon várható eredmény.

\subsection{Biztosítás kötésére motiváló tényezők}

A felmérés kiterjedt arra is, hogy a megkérdezettek mi alapján döntenek egy-egy biztositás megkötése mellett. A válaszadók 1-től 5-ig tartó skálán értékelhették, hogy egyes tényezők mennyire fontosak számukra döntéseik meghozatalában. Ahogyan arra számítani lehetett, a válaszadók jellemzően tudatos döntéseket hoznak, kevéssé hat rájuk a reklám vagy a személyes megkeresés. Érdekes módon ebben a kérdéscsoportban nem vagy csak minimális eltérés mutatkozik az X és az Y generáció tagjai között. (3. ábra)

A válaszadók saját tudatos döntésük fontosságát átlagosan 4,21 pontra értékelték, ehhez képest messze lemaradva következik a saját háztartásban bekövetkező anyagi helyzet, vagy élethelyzet változása mint motivációs tényező 2,88-as fontossági indexszel. A KPMG
A biztositáskötésére motiváló tényezők a teljes mintán
1-töl 5 -ig terjedő skálán értékelve

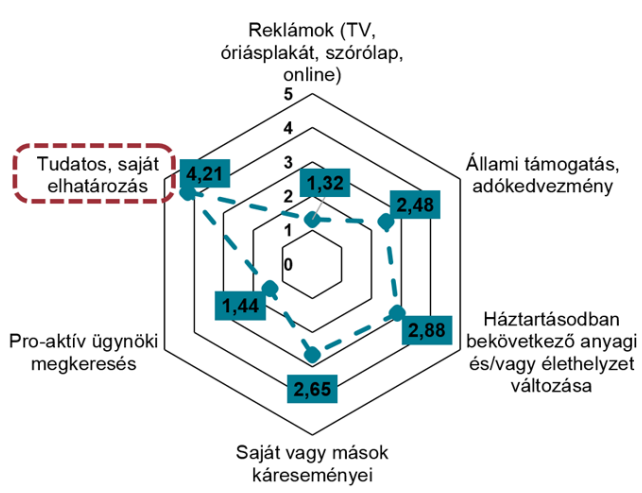

3. ábra - Biztositáskötésre motiváló tényezök (Forrás: KPMG belső kutatás 2015)

dolgozói saját és más kárából is képesek tanulni, 2,65 pontot adtak ennek a motivációs tényezőnek.

Ehhez képest kevéssé befolyásolják a válaszadókat a biztosítók marketingmegoldásai. A reklámok hatását a biztositási döntések meghozatalában mindössze 1,32 pontosra értékelték a megkérdezettek, míg a biztosítási ügynökök megkereséseinek 1,44 pontot adtak. A megkérdezettek 45 százaléka állította, hogy legalább egyszer megkereste már őket biztositási ügynök, zömmel (80 százalék) független közvetitők, kisebb részben (30 százalék, mert átfedés lehetséges) biztositótársaságok call centerei.

\section{Tanulságok a biztosítók számára}

Érdekes módon, mindkét generáció azt állítja, hogy alapvetően tudatos, saját elhatározás alapján köt biztosítást, nem pedig a külső ingerek, reklámok, ügynökök miatt. Ezt valószínűleg némi fenntartással kell kezelni, de ez is megerősíti a korábban mondottakat, hogy nem feltétlenül csak a közvetlen eladás szükséges, hanem a pénzügyi tudatosság fejlesztése, teriesztése is, ami hosszú távon megtérülő beruházás lehet a biztositók számára, akár külön-külön, akár együttes összefogással tesznek ezért.

\section{Nemcsak a közvetlen eladás szuilkséges, hanem \\ a pénzügyi tudatosság fejlesztése is.}

\subsection{Informálódási szokások}

Ha megvan az elhatározás egy biztositás megkötésére, jöhet az információszerzés, hogy konkrétan hol, milyen biztositást érdemes kötni. A kérdőívben éppen ezért kitértünk arra is, hogy a meglehetös jómódban élő, számítógépet, internetet rutinszerủen használó minta tagjai milyen úton szerzik be a döntéshez szükséges információkat. (4. ábra) 
A motivációkhoz hasonlóan e tekintetben is csekély a különbség az X és az Y generáció tagjai között, de már mérhetőnek bizonyult, és a biztosítók marketingkiadásainak jobb célzása érdekében ezt érdemes is megjeleníteni. A válaszadók ebben a kérdéscsoportban 1-től 8-ig terjedő skálán értékelték az egyes információforrás-típusok fontosságát. Jól látható, hogy mindkét generáció tagjai előszeretettel hagyatkoznak azokra a profi oldalakra, amelyek összehasonlítják az egyes biztosítók ajánlatait, ez az információforrás messze a legnépszerübb tájékozódási eszköz a megkérdezettek körében.

A föbb informáló́dási források rangsorolása egy 1-töl 8-ig terjedỏ skálán az

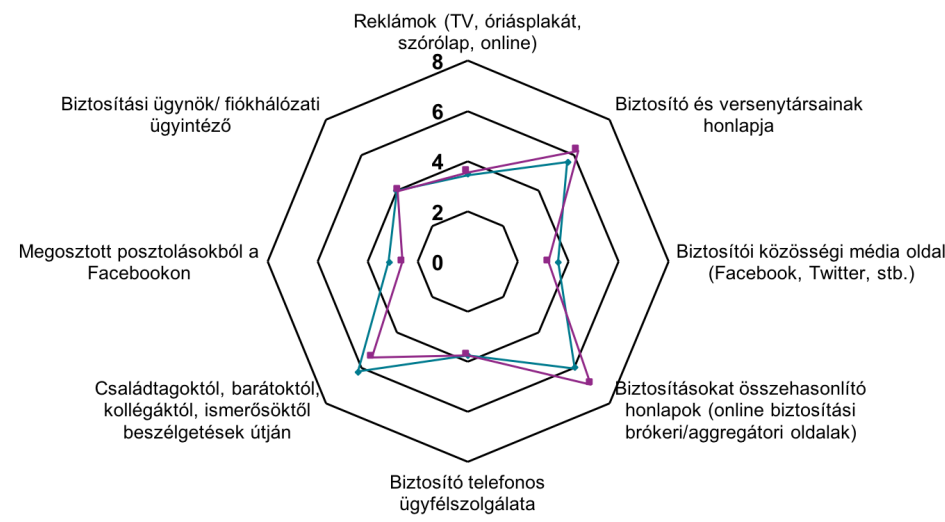

4.ábra - Föbb informálódási források (Forrás: KPMG belső kutatás 2015)

Ezt követi a családtagok, barátok, kollégák megkérdezése. Némiképp meglepő módon a fiatalabbak többet adnak erre az információszerzési módszerre, mint az idősebbek, miközben azok szívesebben támaszkodnak a profi honlapok szolgáltatásaira, mint az Y generáció tagjai, holott az X és az Y generációról felvázolt portrénk ennek éppen az ellenkezőjét sugallja, hiszen az Y generáció számára kevésbé fontosak a személyes kapcsolatok, mint az X generáció esetén.

\section{Tanulságok a biztosítók számára}

Nem annyira meglepő, de mindenképpen tanulságos, hogy a biztosítási ügynökök és a biztosítótársaságok tájékoztatási erőfeszítései a családi/baráti beszélgetések, a biztosító honlapja, illetve az összehasonlító honlapok információs csatornáihoz képest mennyire háttérbe szorulnak. Kérdőívünkben 4 olyan információforrás fontosságának értékelésére kérdeztünk rá, amelyekre biztosítók vagy a független biztosítási ügynökök ilyen-olyan módon pénzt költenek. A szakmai honlapok 6,3-as fontossági indexéhez és a személyes beszélgetésekből szerzett információk alig 6 pont alatti eredményéhez képest a reklámok, a biztosítók közösségi médiás tevékenysége, a telefonos ügyfélszolgálatok, valamint ügynökhálózat mind 4 pont alatti fontossági értéket ért el. Ez természetesen nem jelenti azt, hogy ezeket a csatornákat a biztosítási üzletágban nekellene fenntartani, de azt mindenképpen, hogyaz ügyfél-elégedettség növelésére, az emberek közötti interakció előidézésére érdemes törekedni, ahogyan arra is forrásokat kell előteremteni, hogy a termékünk jól szerepeljen az összehasonlító oldalakon.

\subsection{Igénybe vett értékesítési csatornák}

Az igénybe vett értékesítési csatornák tekintetében a KPMG-nél dolgozó X és Y generációk között jelentős különbségek mutatkoznak. (5. és 6. ábra)

Itt látszik meg igazán a biztosítók által fenntartott ügynökhálózatok jelentősége, mert bár más téren mindkét generáció meglehetősen erős online vásárlási hajlandóságot mutat, bizonyos termékeknél nagyon erős az otthon, ügynökökkel folytatott megbeszélések után rajtuk keresztül megkötött biztosítások szerepe. Tipikusan ilyenek a befektetési egységekhez

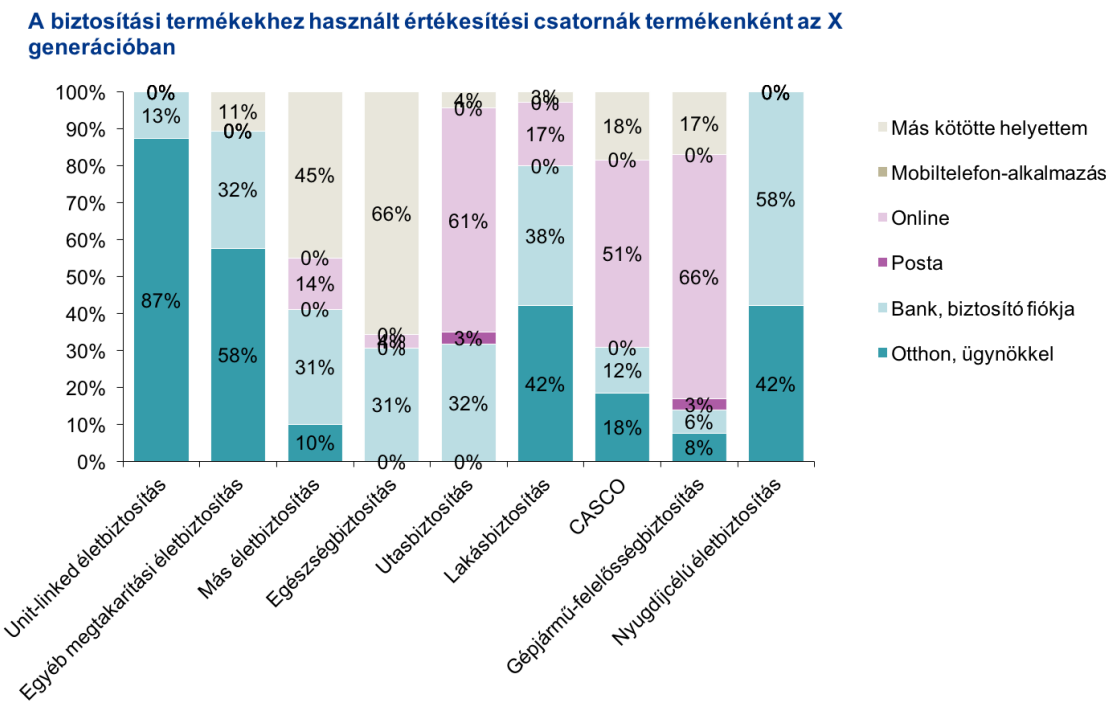

5. ábra - Igénybe vettértékesitési csatornák biztositási termékenként X generáció (Forrás: KPMG belső kutatás 2015)

kötött (unit-linked) biztosítások. Ebben a szegmensben az amúgy erősen számítógéphez kötött, képzett szakemberek is hajlandók személyesen „meggyőzetni” magukat, hiszen az X generációban ezeknél a termékeknél az ügynökök szerepe 87 százalékos, de még az Y generációban is 61 százalékot képvisel. Nem ennyire, de ugyancsak erős az ügynökök szerepe a nyugdíjbiztosításoknál, az egyéb megtakarítási életbiztosításoknál, valamint a lakásbiztosításoknál. Érdekes módon a nyugdíbbiztosításoknál az Y generáció tagjai sűrűbben (73 százalék) veszik igénybe az ügynököket, mint az X generáció tagjai (42\%). Ugyanaz megfordul az egyéb megtakarítással egybekötött biztosításoknál (X: 58\%, Y: 26\%), valamint a lakásbiztosításoknál (X: 42\%, Y: 17\%).

Az online értékesítési csatornák mindkét generációnál nagyon magas értéket kaptak a gépkocsi- és az utasbiztosításoknál. A cascónál, a gépjármű-felelősségbiztosításoknál és az 
A biztositási termékekhez hasznalt ertékesitési csatornák termékenként az Y

generációban

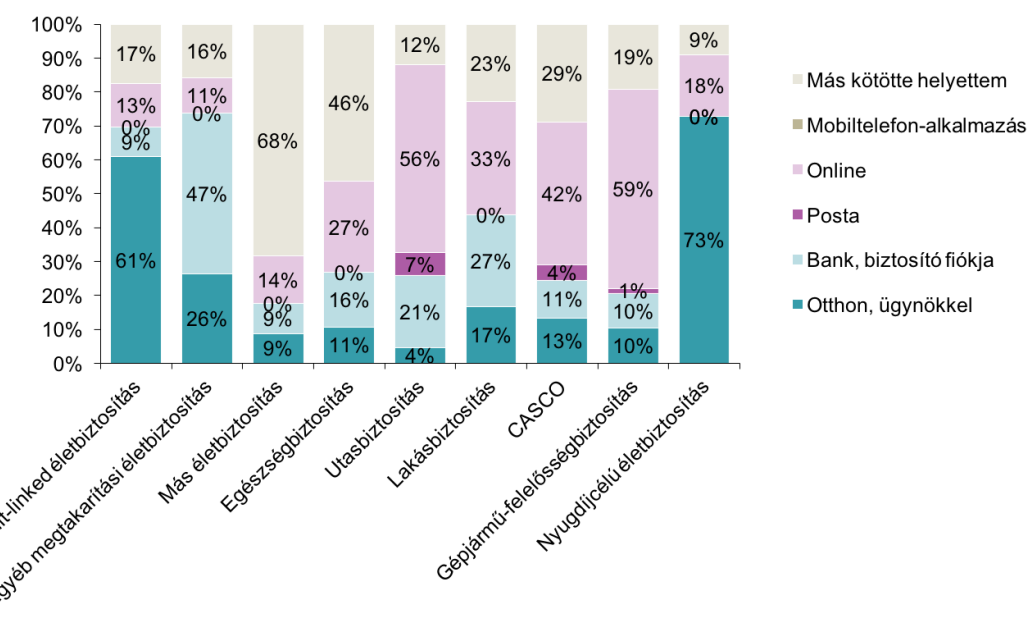

6. ábra - Igénybe vett értékesitési csatornák biztositási termékenként Y generáció (Forrás: KPMG belső kutatás 2015)

utasbiztositásoknál is igaz, hogy az X generáció tagjai nagyobb arányban veszik igénybe az online értékesitési csatornákat, mint az Y generáció képviselöi. A különbségek e téren nem túl nagyok, ám ettől függetlenül meglepő, hogy ezeknél a jól összehasonlítható, meglehetősen homogenizált biztositási termékekné az idősebbek nagyobb arányban veszik igénybe a netet, mint a fiatalabbak, akik ezzel szemben jobban támaszkodnak munkáltatójukra vagy saját cégükre. Ezzel szemben az Y generáció már olyan biztositások esetében is viszonylag nagy arányban használja az online csatornát, ahol az X még egyáltalán nem (unit-linked és egyéb életbiztositás), valamint a lakás-és egészségbiztosítás területén már az online csatorna a legszámottevőbb.

A KPMG maga is sokat áldoz munkavállalóinak egészségbiztosítására, ami visszaköszön abban az adatban, hogy az Y generációs válaszadók 46, az X generációsak 66 százaléka nem maga kötött egészségbiztositást, hanem más kötötte meg helyette. A kockázati életbiztositásoknál fordított az arány, de itt is jelentős a mások által megváltott kötvények száma. Az Y generációnál ebben a szegmensben a biztositások 68 százalékát köti más, míg az X generációnál ugyanez az arány 45 százalékos.

\section{Tanulságok a biztosítók számár}

A válaszokból egyértelműen kiderül, hogy az online értékesítési csatorna ma már gyakorlatilag megkerülhetetlen a legtöbb termék esetében. A gépkocsihoz tartozó és az utasbiztosításoknál is mindkét generáció esetében megkérdőjelezhetetlenül a legelső helyen áll az online csatorna. A biztositók számára érdemes odafigyelni arra, hogy bár a unit-linked és egyéb életbiztositások, valamint az egészségbiztositások esetében az X generáció még egyáltalán nem használja az online csatornákat, az Y generáció szemmel már jól látható része (11-27\%) viszont elkezdte használni ezt, ezért ezen termékek online elérhetősége egyre fontosabb lesz.
A másik tényezö, amellyel számolni érdemes az Y generáció esetén, hogy sok esetben más köti meg számukra, sőt, talán finanszírozza - legalábbis kezdetben - a biztositást, ezért fontos az ügyfelek profilozása, illetve szegmentációja esetében odafigyelni a háztartási kapcsolatok beazonosítására, és a kommunikációt a biztosítási szerződést megkötőre optimalizálni.

\subsection{A legfontosabb tényezők biztosításkötésnél}

Az egyes biztositásfajták választásakor a KPMG dolgozói legnagyobb súllyal a biztositási díjat, az ár-érték arányt, valamint a szolgáltatások minőségét veszik figyelembe. Az 1-töl 5-ig terjedő skálán ezek fontossága szinte minden biztositási termék esetében meghaladta a 4 pontot mindkét generációban. (7. ábra)

A csatorna kiválasztásában meglepő módon ennél kisebb szerepet játszanak az online beszerezhető információk, valamint a barátokés ismerősök véleményei. A legkisebb szerep ebben

\section{A legfontosabb tényezök értékelése biztositásfajták kiválasztásánál} termékenként egy 1 -töl 5 -ig terjedő skálán

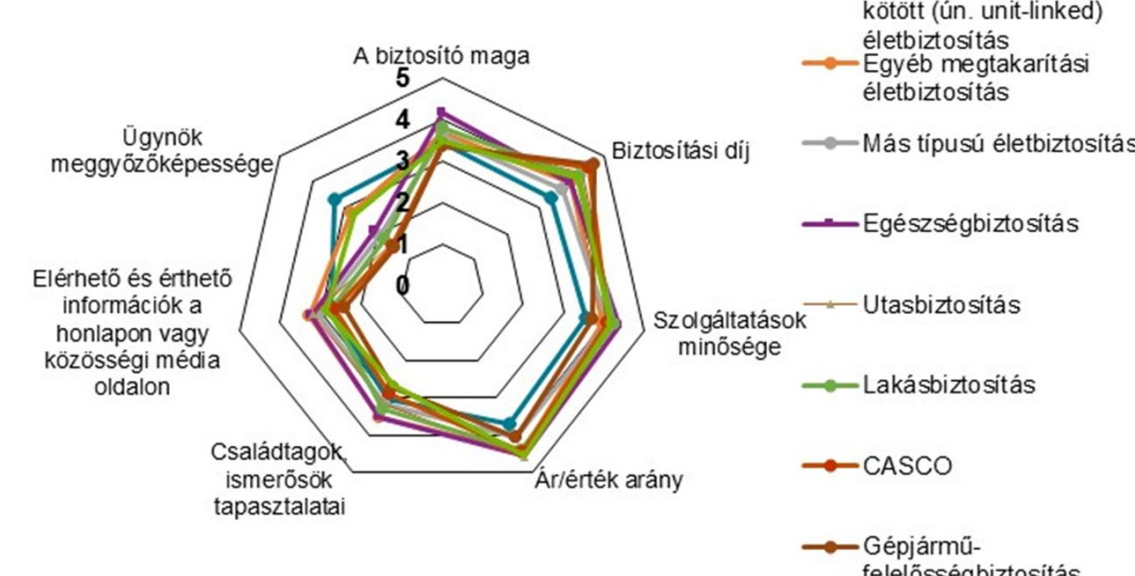

7. ábra - A legfontosabb tényezök értékelése biztositáskötésnél (Forrás: KPMG belső kutatás 2015)

a kérdésben a biztositási ügynököké, akiknek meggyőző erejét a megkérdezettek kizárólag az életbiztosításoknál, valamint a befektetéssel és megtakarítással egybekötött biztositásoknál tartják fontosnak a fiatal menedzserek, de ebben a körben is csak 3-3,5 pont erejéig.

Ezek után némiképp meglepő eredményt hozott az a kérdéskör, amelyben az egyes értékesitési csatornákkal kapcsolatos elégedettségrỏl faggattuk a minta tagjait. (8. ábra)

Messze a legnagyobb elégedettség az online csatornákat illette, ezek mindkét generációtól 5 pont közeli elégedettségi mutatót kaptak. Ugyancsak elégedettek voltak a megkérdezettek 
A legfontosabb értékesitési csatornákról kialakult vélemény egy 1 -töl 5 -ig terjedő skálán generációs bontásban

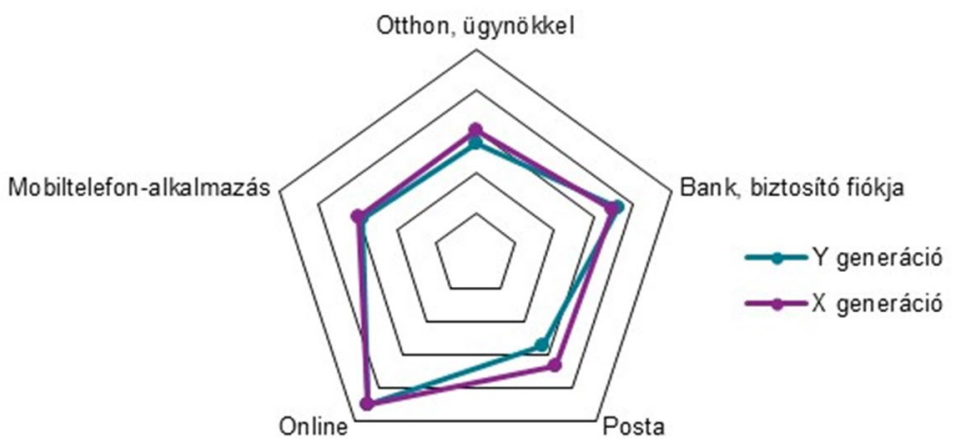

8. ábra - Értékesitési csatornákkal kapcsolatos elégedettség (Forrás: KPMG belső kutatás 2015)

a biztosítók fiókjaival annak ellenére, hogy ezek nem játszanak jelentős szerepet a biztositások megkötésekor szinte egyik termékcsoportban sem. Ezek 4 pont közeli értékelését meg sem tudják közelíteni az ügynökök, akik 3 pontos elégedettségi értékig jutottak annak ellenére, hogy bizonyos biztosítási termékcsoportoknál jelentős szerepet játszanak az értékesítésben. Ugyancsak meglepő módon a megkötött biztositások értékesitési helyei között alig kimutatható postafiókok is jobban szerepeltek az ügynököknél, ezek a X generációtól 3,4-es, az Y-tól 2,9 pontos értékelést kaptak.

\subsection{A biztosítóváltás}

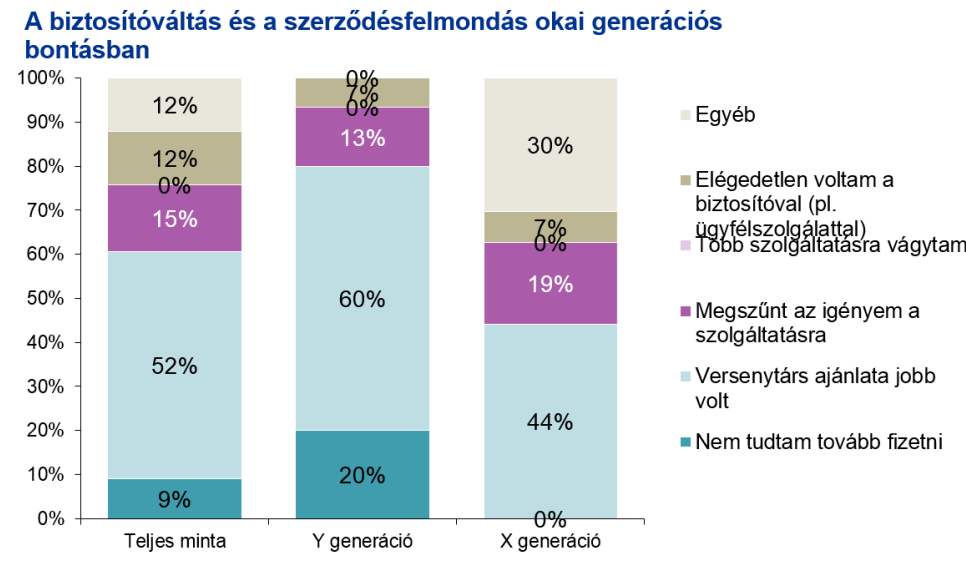

9. ábra - Biztositóváltás okai (Forrás: KPMG belső kutatás 2015)
A kérdőivben az iránt is érdeklödtünk, hogy egy esetleges biztositóváltásnak vagy szerződésfelmondásnak mik voltak az okai. (9. ábra)

Ebben a körben nagyon erös különbségek voltak a generációk között abban a tekintetben, hogy ki, milyen okból mondott már fel biztositást. Noha a fiatalabbakértelemszerűen kevesebb ilyen esetről számoltak be, a felmondás okai között náluk nagyon magas volt a versenytársak jobb ajánlataira való átálás. Lehet, hogy régen igaz volt a „bankkártyát ritkábban cserélnek az emberek, mint feleséget" mondás, de ez az Y generáció tagjaira már egyáltalán nem érvényes. Rövid biztosítotti pályafutásuk során a felmondások 60 százalékát azzal a céllal hajtották végre, hogy elfogadják egy másik biztosító kedvezőbb ajánlatát. Ugyanez az arány a sokkal több szerződést felmondó időseknél csak 44 százalék.

Noha a teljes mintában gyakorlatilag kizárólag felsőfokú végzettséggel rendelkező, jó anyagi körülmények között élő személyek találhatók, a fiatalabbak között előfordul, hogy azért mondanak fel szerződést, mert nem tudják tovább fizetni. Náluk a felmondások 20 százaléka ilyen, az X generációban ez ismeretlen tényező. Az elégedetlenségi faktor mindkét korcsoportban 7 százalékosnak bizonyult, de egyik korcsoportban sem mondott még föl senki biztositási szerződést azért, mert több szolgáltatásra vágyott volna, vagyis az elégedetlenség nem jellemző felmondási indok egyik korcsoportban sem. Annál inkább a biztositási igény megszünése, ilyen okból az X generáció tagjai 19, az Y generáció képviselői pedig 13 százalékban mondtak már fel szerződést.

\section{Tanulságok a biztosítók számára}

A legfontosabb tanulság talán az, hogy az Y, és valószínüleg az azt követő generáció megszerzéséért és megtartásáért sokkal többet kell tenni, mint eddig, és egyre nagyobb jelentősége lesz a proaktív megtartási kampányoknak és a folyamatosan versenyképes, testreszabott ajánlatoknak.

\subsection{Biztosítóválasztás és lojalitás}

Az előbb már láthattuk, hogy a fiatalok körében a versenytársak jobb ajánlata gyakrabban vezet a szerződés felmondásához, mint az idősebbek körében. Mégsem mondhatjuk, hogy a X generáció lojálisabb lenne biztositójához, mint az Y. Ennek hátterében az áll, hogy az idősebbeknek több élő biztosításuk van, mint a fiataloknak, és tudatos vásárlóként az újabb és újabb biztositási termékeket nem egy másik területen jól teljesitő biztosítójuknál váltják meg, hanem körülnéznek a piacon, és az adott pillanatban legjobb ajánlatot fogadják el. Így lehetséges, hogy noha alacsonyabb arányban mondanak fel szerződéseket jobb ajánlatok kedveért, mégis számottevően több biztositótársasággal állnak aktuálisan kapcsolatban, mint az Y generáció tagjai. Míg az Y generáció mintegy fele egy biztosítóval áll kapcsolatban, addig az X generáció 58 százaléka hárommal vagy annál is többel, ami az Y generációnak csak 29 százalékáról mondható el. (10. ábra)

A KPMG-s dolgozók körében a biztosítóválasztás elsődleges szempontja a jó tapasztalat, és ebben nem mutatkozik szignifikáns különbség az X és az Y generációk között. 
A mintában szereplök megoszlása attól függöen, hogy hány biztositónal kötötték meg meglévö biztositásaikat, generációs bontásban

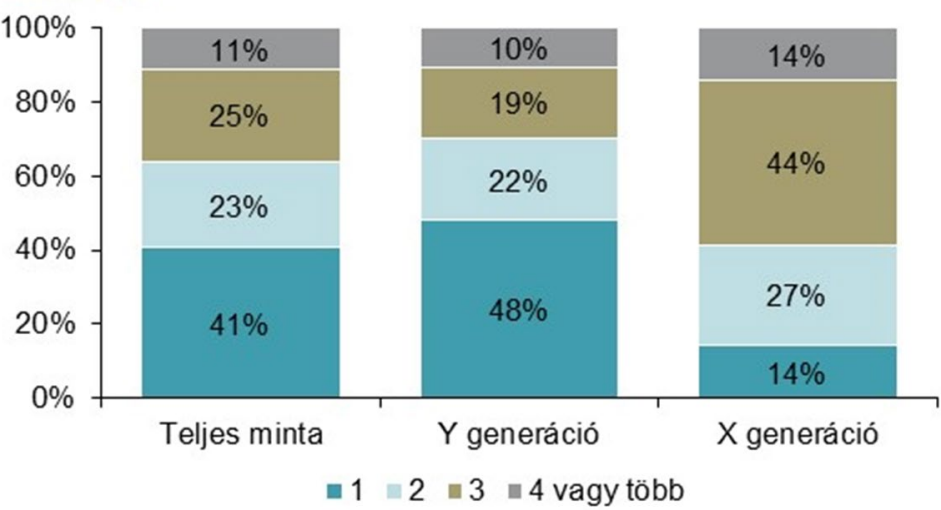

10. ábra - Biztositói kapcsolatok száma (Forrás: KPMG belső kutatás 2015)

Ez némiképp ellentmond annak, hogy mennyire nem lojálisak egyébként biztositójukhoz a megkérdezettek. Közvetlenül az adott biztosítóval kapcsolatos jó tapasztalat után a választásban második legfontosabb tényezőként az ár jelenik meg. Fontos, de az 5-ös skálán már csak 4 pont körüli súlyt kap mindkét generációtól a biztosító jó hírneve és mérete, amitől stabilitást remélnek a biztosítottak. (11. ábra)

Itt is meglátszik, hogy a KPMG-s dolgozókra mennyire nem hatnak azok az információk, amelyeket maguk a biztositók próbálnak feléjük közvetíteni. A jó honlap még viszonylag fontos tényezőként szerepel a megkérdezettek fejében, de ezt is inkább a felhasználói élmény és praktikum felől közelítik meg, a biztosítók közösségi oldalai, reklámjai, elnyert díjai és társadalmi szerepvállalásuk viszont egyáltalán nem számíta-

A biztosítóválasztásnál fontos szempontok generációs bontásban egy 1-től 5-ig terjedő skálán értékelve

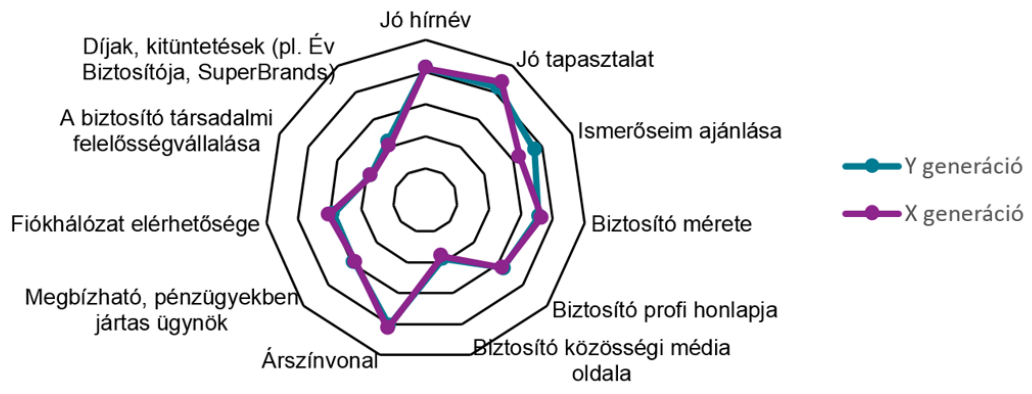

nak a biztosítóválasztást meghatározó körülménynek számukra, ezek a tényezők 2-es fontosságot érdemeltek csak ki az 5-ös skálán.

\section{Tanulságok a biztosítók számára}

Érdekes látni, hogy az $\mathrm{X}$ generáció 58 százaléka 3 vagy több biztosítónál rendelkezik egyszerre szerződéssel, ami komoly potenciált jelez a keresztértékesités (cross-sell tevékenység) hatékonyságánakjavításában. Ebben is nagy segítséget jelentenek az adatelemzésen alapuló módszerek, mint az NBO (next best offer) vagy a termékaffinitási modellek.

Biztositóválasztás esetén is igaz a nagyon erősárérzékenység, mint minden más szektorban, így versenyképes árképzés nélkül egyértelműen nem lehet sikert elérni a piacon. Emellett fontos látni, hogy mind a saját, mind az ismerősök/barátok által megélt jó tapasztalat szintén kritikus a biztositóválasztásnál. Az ügyfél-elégedettség folyamatos mérése, a beazonosított problémák gyors orvoslás és az elégedetlen ügyfelek kezelése hosszú távon versenyelőnyt jelent.

\subsection{Elégedettség a biztosítási termékekkel}

A biztosítási termékekkel kapcsolatos elégedettséget azon a kérdésen keresztül teszteltük, hogy a minta tagjai mennyire szívesen ajánlanának egy-egy biztosítási terméket barátaiknak, rokonaiknak. (12. ábra)

A válaszokból az derül ki, hogy komoly eltérések vannak mind egy generáción belül, mind a generációk között az egyes biztosítástípusok ajánlására való hajlandóságot illetően.

Az X generáció szívesen ajánlaná másoknak unit-linked és egyéb megtakarítási életbiztosítását, egészségbiztosítóját vagy utas- és lakásbiztosítóját, vagyis leginkább ezekkel elégedett (rendre 46, 35, 31, 31 és 33 százalék), míg a fiatalabbak az utóbbi három biztosításfajtával nem A biztositását szivesen ajánlók aránya az összes biztositássa

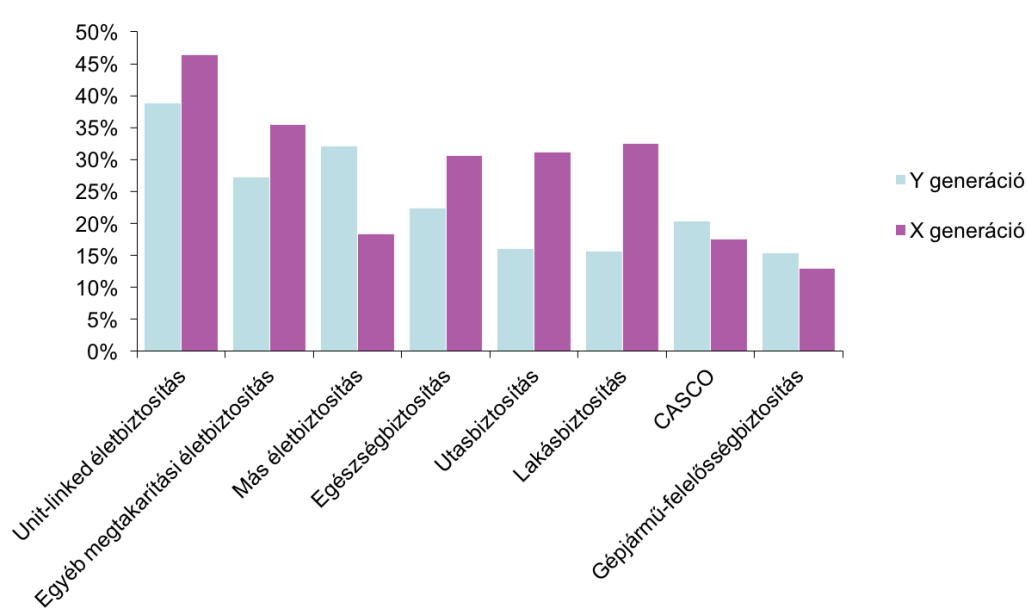

12. ábra - A biztositását szivesen ajánlók aránya (Forrás: KPMG belső kutatás 2015) 
annyira komfortosak, csak 22, illetve 16-16 százalékuk merné másoknak ajánlani a fenti sorrendben. Mindkét generáció viszonylag elégedetlen a két, gépjárműhöz köthető biztosítási termékcsoportban kapott ajánlatokkal, ezeket 13-20 százalékuk merné csak másoknak is ajánlani.

A sajtó és a közbeszéd a unit-linked típusú biztosításokkal kapcsolatos problémáktól volt nem is olyan rég hangos, ezért az egyik legmeglepőbb eredmény (legalábbis a szerző számára) ezen biztosítások nagyon magas ajánlási aránya.

\section{Tanulságok a biztosítók számára}

A kérdőív alapján az okokat csak találgatni lehet, de van néhány olyan eredmény, amelyet a biztosítóknak érdemes alaposabban megvizsgálniuk. Mi az oka a gépjármü-biztosítások nagyon rossz megítélésének, különösen az X generációnál? Mi az oka annak, hogy az Y generáció alapvetően majdnem minden biztosítást illetően kevésbé tünik elégedettnek? Ez utóbbi kérdés vizsgálata talán a legfontosabb, mert ennek alapján úgy tünik, hogy lassan a biztosítottak derékhadát adó generáció igényeinek már nem felelnek meg teljesen a jelenlegi értékesítési, kiszolgálási stb. módszerek, folyamatok.

\subsection{Nyitottság az innovációra}

Jó úton jár az a biztosító, aki a jól kereső, felsőfokú végzettségü ügyfélkört profi online megoldásokkal igyekszik megnyerni, de hibáznak azok, akik ezt kizárólag mobil appokon keresztül képzelik el. A KPMG-ben dolgozó fiatal, jól kereső és jól képzett munkavállalók válaszaiból legalábbis az derül ki, hogy bár szeretik a jól sikerült online megoldásokat, a biztosítókkal nem a villamoson akarnak kapcsolatba lépni, hanem az íróasztaluknál, nyugodt körülmények között. Erre utal, hogy amikor arra kértük őket, hogy 5-ös skálán értékeljék, milyen innovációs irányokat tekintenek mérvadónak, messze a legmagasabb pontértéket (4,54-et) az online szolgáltatások érték el, ugyanakkor a mobil appok jelentőségét csak 2,65 pontra értékelték a megkérdezettek. Ennél fontosabb szempont a megkérdezettek körében a személyre szabhatóság, ami azért meglepő, mert az ezt megalapozó utókövetést ennél lényegesen kevésbé fontosnak (2,35 pont) értékelték.

\section{Fontos tapasztalatok}

- A magasan képzett, jól kereső csoportban elvégzett kutatásunk azt mutatja, hogy van némi diszkrepancia aközött, hogy hogyan gondolkodnak magukról a csoportba tartozók, és hogyan viselkednek a valóságban. Úgy látjuk, hogy a csoport tagjai túlértékelik saját tudásukat, ugyanakkor leértékelik mindazokat az információkat, amelyek maguktól a biztosítóktól, azok képviselőitől vagy ügynökei felől érik el őket. Ennek ellenére mindkét csoportban magas azoknak az aránya, akik a bonyolultabb, nehezebben összevethető, kevésbé homogenizált biztosítási termékekről már nem akarnak egyedül dönteni, hanem bevonják a biztosítók képviselőit is ezekbe a döntésekbe.

- Bár azt feltételeztük, hogy az X és az Y generáció tagjai erősen támaszkodnak döntéseik- ben a közösségi médiás tartalmakra, az ott fellelhető információkra, ez a hipotézis nem bizonyult valósnak. Mindkét generációban magasabb a személyes tapasztalatok alapján hozott döntések befolyásoló ereje, mint bármilyen közösségi médiás információforrás, de az online csatorna, ami mind a biztosító honlapjait, mind az összehasonlító oldalakat jelenti, megkerülhetetlen információszerzési és eladási csatornává vált a legtöbb termék esetében.

- Az X és az Y generációkról alkotott képünk nem minden termékkel kapcsolatos választásban érvényesül. Az Y generáció - feltehetőleg életkori adottságok miatt - bonyolultabb döntések előtt kifejezetten keresi a személyes tapasztalatokat.

A hosszú távú tervezést igénylő termékeknél, mint a nyugdij- vagy egészségbiztosítás, még a magas pénzügyi tudással rendelkező emberek - mint az adott minta X és Y generációs tagjai egyaránt - sem viselkednek racionálisan, hiszen félelmeik ellenére erösen alulbiztosítottak. Ezen valószínűleg csak hosszú távon, társadalmi edukáció útján lehet változtatni, de a termékfejlesztésnek is figyelembe kellene vennie ezt a problémát.

*Szőke Péter, Igazgató, Data \& Analytics Üzletág, KPMG Tanácsadó Kft. (e-mail:peter.szoke@kpmg.hu)

Kulcsszavak: Generation X and Y, Survey methods, Customer habits, Personal finance JEL: J100, C83, D14

\section{SUMMARY}

In everyday life we often face the fact that younger generations think and act differently. In May 2015 KPMG did a research to reveal whether the general differences between generation X (people born 1965-1979) and generation Y (people born 1980-1995) are also reflected in their insurance habits. How and how much insurers should adapt or differentiate their strategies and processes to fulfill the expectations of both the younger generation $\mathrm{Y}$ and the more affluent generation $\mathrm{X}$.

The survey questions were formulated around ten areas of interest to reveal generational differences: saving habits, fears vs. insurance, motivating factors for buying insurance, information sources used, sales channel preference, most important factors for choosing an insurance, most important factors for choosing an insurer, satisfaction with different insurance products and openness to innovation.

\section{FELHASZNÁLT FORRÁSOK:} Kulcsár Zsolt: Az integratív e-learning felé, http://wwww.crescendo.hu/konyvek/integrativ-e-learning, Kiadó:Kulcsár Zsolt,
KPMG biztositási szokásokat vizsgáló belsö kutatás, 2015 . 